\title{
Strategic planning in the family business of the Chinese community of Mexicali, Baja California, Mexico
}

\author{
Zulema Córdova Ruiz ${ }^{1}$, Loreto María Bravo Zanoguera ${ }^{2}$, Sósima Carrillo², \\ Ana Cecilia Bustamante Valenzuela ${ }^{2}$, Sofía Lizzett Reyes Ayala ${ }^{1}$, Lourdes Patricia Escobar Pérez ${ }^{1}$ \\ ${ }^{1}$ Master in Management, Faculty Administratives Sciences, Autonomous University of Baja California, Mexico; Research Areas: \\ Management, Finance and Accounting \\ ${ }^{2}$ Doctor of Administrative Sciences, Faculty Administratives Sciences, Autonomous University of Baja California, Mexico, Research Areas: \\ Management, Finance and Accounting
}

\section{Email address:}

zulema.cordova@uabc.edu.mx (Z. C. Ruiz), loreto@uabc.edu.mx (L. M. B. Zanoguera), sosima@uabc.edu.mx (S. Carrillo), ceci@uabc.edu.mx (A. C. B. Valenzuela), lizzettreyes@uabc.edu.mx (S. L. R. Ayala), pescobar@uabc.edu.mx (L. P. E. Pérez)

\section{To cite this article:}

Zulema Córdova Ruiz, Loreto María Bravo Zanoguera, Sósima Carrillo, Ana Cecilia Bustamante Valenzuela, Sofia Lizzett Reyes Ayala, Lourdes Patricia Escobar Pérez. Strategic Planning in the Family Business of the Chinese Community of Mexicali, Baja California, Mexico. Science Journal of Business and Management. Vol. 2, No. 5, 2014, pp. 116-122. doi: 10.11648/j.sjbm.20140205.11

\begin{abstract}
Small and Medium Enterprises (SMEs) due to their participation in the production of goods and services and as a source of jobs, are the basis of the economy in any country. In Mexico $95 \%$ of the companies have a family structure or are controlled by a family, so it is important to identify strategies that favor their continuation over time. This research was conducted in order to analyze the strategies that SMEs have implemented that have allowed them to remain in the market. In the process were applied 30 questionnaires to the founders and managers of small family businesses constituted by members of the Chinese community situated in the city of Mexicali, Baja California, Mexico. These companies develop activities and a strategy based on experience, and show a marked reluctance to invest time and effort in designing strategic planning, is why is essential carry out actions that will help them continue the operation of its business with, in order to achieve their permanence, growth and consolidation.
\end{abstract}

Keywords: Strategic Planning, Strategy, Family Business, Chinese Community

\section{Introduction}

Nowadays organizations suffer intense pressure from its competitors; every day arise new products or services that can replace the previous, so businesses should always seek improvement in the quality of what they offer. In order to survive and sustain itself, companies must maintain a continuous process of warning and must be prepared to adjust and adapt to changing environmental conditions. The main objective of strategic planning is to set the foundations for the preservation of the organizations even in the changing conditions of business context.

China is a country with different social structures, cultural norms, and relationships manners. This nation has traditions rooted and strong moral values born of a long history and have endured over time. Given this situation, trying to inquire into how the businesses managed by members of the
Chinese community have faced dynamics in economic reality of the environment, this research analyzes the strategies that have given permanence to businesses and even favored their consolidation. Family businesses become good practice in society, since the fact of building a company through such an important core such as the family, is a challenge, because the members must generate themselves the necessary strategies to keep a good control, good management decisions and preserve the company for generations (Cisneros, 2007).

\section{Background}

Currently, Mexicali has a population of just over 900,000 inhabitants, according to figures from this last population census in 2010 (INEGI 2010), of which about 40,000 are of 
Chinese origin, based in information by the Chinese business chamber of Mexicali. In the late nineteenth century a strong Chinese immigration arrived to the United States in order to work on the construction of railways and irrigation channels. Upon completion of these works, the United States began to reject them and even issued a law prohibiting their entry in 1904. This almost coincided with the agricultural development of Mexicali that required manpower because existing Mexicans were insufficient at that time to provide it. For this reason, from 1910 to 1920 , the entry of Asian workers in this region was provided, which were predominantly settled in what later became known as "The Chinesca". Chinatown still exists downtown. Over time, these immigrants occupied spaces such as lessors of land, subsequently in commerce, mainly restaurants.

In 1918, a group of Chinese single men founded the China Association with the purpose of representing the community before governmental or civil entities and to promote their culture, strengthen the moral principles and affirm the bonds of family togetherness. Through this partnership were made the first acts of public beneficence and was made the first public hospital, funded by Chinese farmers with donations coming from their crops of cotton. The control of agriculture by them was amazing. During the first decades of the century, some Chinese became successful entrepreneurs. A midtwentieth century, Chinese community members set up different sales businesses of clothing, footwear, haberdashery, grocery stores and restaurants; this benefited to the economic development of Mexicali because of the generated workspaces and the prosperity in the local economy. This situation continues today as they offer more than 1,200 sources of employment for city workers (Arellano, 2012).

\section{Problem Approach}

There is no model that integrates the capabilities and resources of family businesses that help them become more professional, defining professional as the internal capacity of a family business to structure, to manage and to govern the resources and capabilities to achieve its objectives (Basco, 2006). There is no a theory that fits the needs of family businesses, since most of the related investigations focus on recognizing and appreciating their characteristics, thus the needs having the most family businesses about their functioning and survival represent a challenge to undertake such research. Despite the large number of family businesses of Chinese origin in the region (particularly in Mexicali) that give employment to a significant part of the population representing large share of GDP, many of this businesses fail due to mismanagement, that includes the lack of strategic planning.

\section{Literature Review}

Societies evolve over generations; in same way like species do, organizations that survive are not the larger ones not the ones that have more resources, organizations that survive are those who manage to adapt and meet the constants demands and challenges of the environment.

Those that survive not only have the ability to adapt but to anticipate the change and to create conditions that impact the environment and other organizations. In the measurement they anticipate to these changes proactively, it will his success. Strategic planning is a tool that supports the achievement of these results.

Strategic planning is directly related to the Theory of Resources and Capabilities of the Company, it hold that competitive advantage and growth of organizations in because they possess unique resources and capabilities that differentiate them from other competitors in your industry, so you might consider that apparently similar firms obtain different results.

To plan is to choose and set a goal; is to develop a project and specify the steps to carry it out by calculating the risks that glimpse; is how to prevent and avoid the threats for minimized; is to be prepared continuously for obtaining good results. The planning must seek to ensure the permanence of business to formalize the plans, programs and procedures so they operate in congruently against eventualities that arise in the daily walk of organizations.

The strategy is a choice that involves the entire organization and that is to select from among several alternatives the one which suits better, considering all those internal and external factors that surround it and, based on that choice, make decisions always looking for a better future position in relation to the current situation.

A good strategy should be able to achieve the desired objective; should be able to make a good connection between the environment and resources of an organization and competition; should be doable and appropriate; should be dynamic, flexible and able to adapt to changing situations. A good strategy should be able to provide the organization with a competitive advantage.

To Chiavenato (2011), strategic planning is a process in the organization that is in charge of drawing the guidelines to define action plans that generate competitive advantage and sustainability over time. Strategic planning is to develop, build and implement the various plans by companies or organizations with the intention of achieving the objectives and goals pursued in terms of opportunities and threats offered by the environment.

It is important to note that strategic planning does not attempt to make decisions by looking to the future, but rather by responding to certain problems of the present; therefore is not in charge of forecasting future sales, but of solving current problems that could be related to them. Because of this is that all companies must constantly review its strategic planning and creating new plans to resolve those conflicts that could affect this. In this regard is essential that all persons working with management can develop their knowledge and understanding of the exact needs of the company, for that the strategic planning allow them to interact with a dynamic world and evolving.

Strategic management comprises five stages: establishing 
of organizational direction, diagnosis, strategy formulation, implementation and evaluation of results (Hill and Jones, 2009). In the organizational direction are made actions such as the generation of mission, statement of some desired future state named organizational vision, and in the same way becomes priority the establishment of objectives, statement of values, goals and action plans. As a second step must be performed the analyzes both internal and external environment of the organization, and over all the developing of strategies to generate competitive advantages that will help strengthen the business. Not forgetting the development of internal and external diagnostics to set objectives.

\section{Organization and Family}

In order to provide a precedent about the concepts of enterprise and family business, it is first necessary to establish the concept of organization. Kast and Rosenzweig (2004) tell us that groups and organizations are an important part of our existence. Usually we born in a family, we continue our live in contact with various institutions. Organizations differ from informal groups because they arise spontaneously when several people with common interests match to common goals. An organization is a system with a purpose, in which its parts have own purposes, it differs from one company because it performs six types of exchanges (Ackoff, 1997):

- Money exchange with employees for their work

- Money exchange with consumers for goods and services

- Money exchange with suppliers

- Goods and services exchange with government

- Money exchange with investors and lenders for accounts payable

- Money exchange with debtors for accounts receivable

In the accounting theory, exist postulates that were defined considering the different schools of thought developed decades ago and also the practice of business. However, these assumptions may change if you change the environment in which the accounting information system operates. One of these principles is that of "going concern" that set that the economic entity is presumed in permanent existence within an unlimited time horizon, while prevailing the favorable conditions for the development of their activities. Alejandro Alcocer defines the company as "an economic entity of production or distribution of goods or services, in which human, physical, and technical elements interact to fulfill a purpose or activity" (Alcocer, 2009).

A definition that has been used in several studies is defining the family business as "one business where family members dominate the ownership and management of the firm, and perceive the company as a family business" ${ }^{1}$ (Ghua

[1] Ghua, J., J. Chrisman \& P. Sharma. 1999. "Denning the family business by behavior". Entrepreneurship Theory and Practice, 23(4). Dreux. I. \& B. Brown. 1999. Marketing private banking services to family businesses. Consultada en http://www.genuresources.com/Mark.priv.bank. Dreux_5.html. et al., 1999; Dreux \& Brown, 1999; Gersick et al, 1997; Litz, 1995).

For its part Rodríguez (2006) tells us are "basic production units, responsible for carrying out economic activities that allow us to meet human needs, consist of a group of people and a variety of resources (material, financial, technical)"2.

The small company has provided one of the best alternatives for economic independence, since these businesses have become a great opportunity to economically disadvantaged groups that have been initiated and consolidated because of their own merit. Similarly it should be noted that small business provides the experimental field to generate new products, ideas, techniques and ways of doing things. The importance of small business should not only be measured by the number of establishments or invested capital in them, but also must consider the jobs and training that generate and the purchasing power given to workers by wages and salaries.

\subsection{Family Business}

For Casillas and Acedo (2007) the family business is not as easy to define as there are some fuzzy boundaries. In general is one where more than one individual, one family, has the company as a way of life, family businesses are the combination of three subsystems: family, ownership and control. At birth, these three subsystems are completely overlapping. Family businesses are those that are passed from one generation to another (Ward, 1987), according to the Institute for Family Business, 80 or $90 \%$ of businesses in America are family businesses, in Mexico, 95\% of the 65,000 medium and large Mexican companies are family businesses, which have a very big challenge to evolution, which consists precisely in their separation, or survival and consolidation in the third generation.

Every knowledge area must be built on a theoretical basis. In the field of business administration, the primary source of material consists of extensive experience and vast literature that exists on this issue, however, respect to the management of family businesses there is a lack of theoretical integration and empirical, plus it not exist not have a unified definition.

This lack of theoretical integration make that there are many definitions of family business. In the United States are reported more than twenty definitions; in Mexico the few professionals that are dedicated to this discipline also handle various definitions. Although there is no consensus on the definition of family business, most of the experts associated with the controlling and direction of the organization in the hands of family members.

For Longenecker (1994), a family business is one that meets two basic requirements: first about property, all

Gersick, K., J. Davis, M. Hampton \& I. Lansberg. 1997. Generation to generation: Life cycles of the family business. Boston, MA: Harvard Business School

Litz, R. 1995. "The family business: Towards definitional clarity". Family Business Review, 8(2)

[2] Rodriguez, J (2006): How to apply strategic planning to small and medium enterprises, Fifth Edition, International Thomson, Mexico. 
members or at least the capital proportion needed to maintain the control of the organization must belong to two or more members of the same family; and second about management, at least two of the family members must be involved in the operation of the enterprise. This means that is not enough having the controlling interest in the company, at least two of the family members must be actively working in the company. Although no precise data that provide the accurate proportion who keep the family companies with which those are not because the census does not classify firms as familiar and unfamiliar, some authors mention that globally between $80 \%$ and $90 \%$ of companies in the world are family business, generating $75 \%$ of world GDP and employing $85 \%$ of the working population, reason why they are considered an economic and social engine worldwide (Poza, 2005). In addition, Rodriguez Valencia mentions that of the over $2,000,000$ companies operating in Mexico, 98\% are controlled by a family or have a strong intervention by the members of this.

The above paragraph shows the importance to deal with this topic. Nonetheless, family businesses in Mexico have a life expectancy of 25 years (Urzua, 2012). While each organization has its own members, goals and values, it has been found possible to establish dissimilarities between family businesses and those that are not. Some of the distinctive features of family businesses are that, in the beginning, they tend to get little or no debt and are often economically underdeveloped, in the sense that they are not as great as they could be. Another feature is that, at times, family businesses usually operate without a bureaucratic system, so that decisions are taken quickly and therefore are able to adjust quickly to changes in their environment. Another characteristic is that since in these companies, the business and family subsystems interact, the interests of the family play an important role in decisions making, letting beside purely rational decisions. Finally some family businesses tend to be oriented towards sales and production, leaving areas as finance and marketing in a second level, even if these are also important and should be considered when planning activities organization.

Early researchers of family business were consultants of family businesses, often family financial advisors or therapists (Lansberg, 1988), which began to suggest to family businesses some ways to prevent errors from critical situations, such as the role of leadership in the company, the general administration of the company, the compensation of family employees, communication between members of the business and the family, succession planning and risk management (Katz, 2005).

\subsection{Chinese Company}

The figure of the "family man" still has a strong preponderance to establish to man as head of household and the elderly are respected. The same treatment given to adults into the Chinese community is give to them into their organizations, becoming an important and recognized hierarchy. As a general principle, the Chinese citizen is very entrepreneurial, with strong predisposition to resolve the concerns of their customers. He is very active in participation within their organizations, has a clear tendency to permanently overcome himself by incorporating training and equipping to their companies. The continued growth of their companies is surprising.

Moreover the Chinese people are very cordial, friendly and helpful. They are always trying to solve all obstacles; are very detailed and pay attention to provide cares like transportation, company reception and reservations; that make the visitor is predisposed for business. The Chinese do not perceive the work as a punishment, the Chinese do not have the religious idea of 'earn their bread by the sweat of his brow', and so the work is a way to give dignity to their lives. One of the most striking aspects of small Chinese merchants in Mexicali is their long working hours, with hours that extend far more than usual. Chinese owners have the thought that the longer the business is open, the more chance there is to make money. They have an adage: "if you maintain the store open, won't know how many customers will attend, but if you have the store closed, surely will be no one".

\section{Methods/ Procedure}

The objective of this research over of small family businesses Chinese origin in Mexicali, Baja California, is to determine if the factors of their permanence are the proper implementation of strategic planning and its basic elements such as relevance, reliability, time horizon and use strategic tools. The investigation was of mixed type, combining qualitative information obtained from experts and quantitative information obtained through the application of interviews about strategic management variables and designing of business strategies. The design is experimental, not descriptive, cross because data were collected in a single moment in its natural context, through interviews with the founders and managers; having as purpose to describe variables and analyze their effects (Hernandez Fernandez y Baptista, 2014).

In the first phase of the investigation proceeded to characterize family businesses, for they have the internal capacity to structure, manage and govern their resources and capabilities in order to improve their competitiveness and enhance their stay. In the second phase, developed a questionnaire with open questions (as interviews) to a sample of 30 companies belonging to the Chinese community about who or who are the people who founded the company and if still work on it; who did the major business decisions; if within its administrative practices developed organizational manuals, implementation of policies and strategies; and if considered relevant to know to direct competition. The information from the questionnaires was processed and statistically analyzed in SPSS. 


\section{Results}

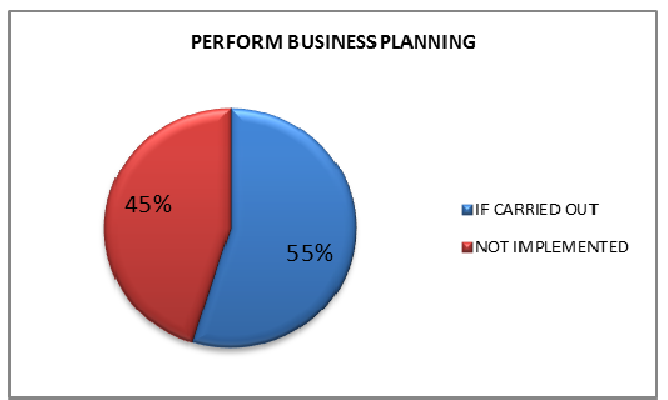

Fig. 1. Perform business planning.

As figure 1 show, $55 \%$ of family business owners develop planning process in their companies, however a high percentage (45\%) ignores this activity, which results in a administration lacking of tools that support the business continuity.

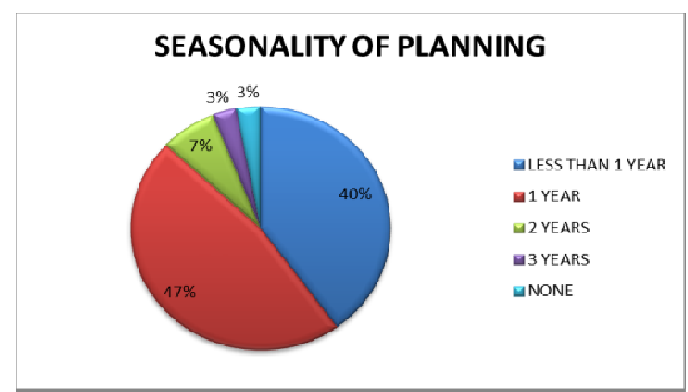

Fig. 2. Seasonality of planning.

Figure 2 refers to the period of time in which planning is projected. The results show that $47 \%$ of SMEs plan to 1 year. This result may indicate that adhere to a short-term trend, an operational approach, rather than a strategic trend (long term) In addition it can be mentioned that the companies which showed a longer time horizon (over 1 year), obtained superior performance. This result suggests that the long-term time horizon implies some advantages over short-term planning.

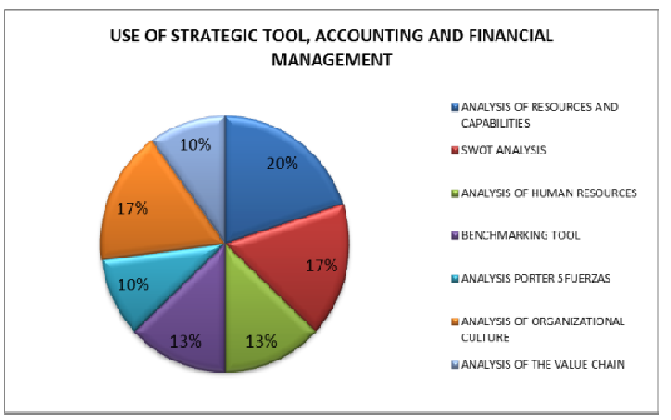

Fig. 3. Use of strategic tools, accounting and financial management.

Regarding the use of strategic tools, figure 3 exposes that we found that the most frequently used tools are: the analysis of resources and capabilities of the company, with $20 \%$; analysis of strengths, weaknesses, opportunities and threats (SWOT), with $17 \%$; and analysis of organizational culture
(17\%). The analysis results show that SMEs that make greater use these instruments have a more formal strategic planning. These results support other studies that have found that companies that use strategic tools experienced a positive and significant effect between the formality of planning, more effective implementation and superior performance. However, a limited use of these tools can be seen, particularly as they relate to strategic issues.

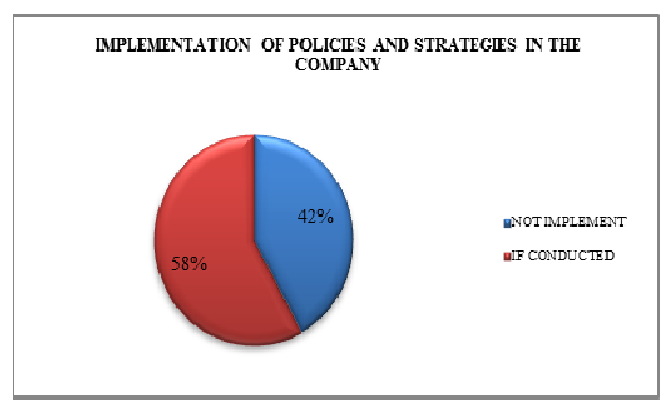

Fig. 4. Implementation of policies and strategies in the company.

$42 \%$ of companies lack the development of policies and strategies, this is one of the reasons they not have made a proper implementation. Only $58 \%$ of companies focus on the process of developing policies and strategies.

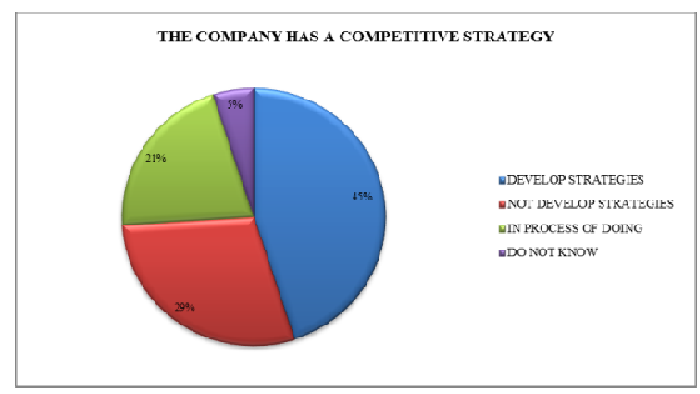

Fig. 5. The company has a competitive strategy.

Figure 5 shows that $45 \%$ of the family business have a strategy to compete as a common practice, $29 \%$ do not have a strategy, and 5\% did not know about the need of this.

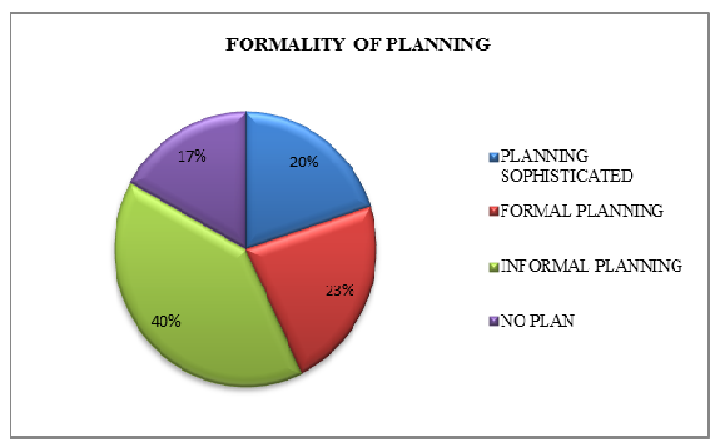

Fig. 6. Formality of planning.

In the survey conducted, the planning was divided into four levels: sophisticated, formal, informal and without planning. The criterion used was based on: (1) whether the plan was written; and (2) whether it met the requirements of 
a formal planning. In figure 6 the results obtained show that only $20 \%$ of SMEs have a sophisticated planning and $23 \%$ have a formal planning. However, $17 \%$ have no planning and $40 \%$ do so informally, that is, does not have a written plan. When performing a deeper analysis of the data, the results suggest that there may be more likely to improve business performance through the application of a formal planning process, than through an emergent and informal process. We also found that companies that have sophisticated planning have higher performance than those which do informal planning or not do that.

\section{Conclusions}

It found that there are significant differences between the size and years of operation of the company, compared to the level of formality of planning, this supports the idea that companies go through various stages of development and by the time they mature and become more complex, they will require to formalize their planning processes. The family business, face difficulties to stay competitive and profitable in the market, so they have the need to undertake innovative strategies that help them meet and overcome the challenges that they will be exposed in its current context. The lack of planning can result in excessive contingency, absence of a measure to monitor the success or failure of management, lack of a clear vision and lack of control, causing waste of time, resources and opportunities.

Among the factors that influence the permanence of small family businesses of Chinese origin in Mexicali Baja California, from analyzing organizational approach, the concepts of trust and communication between family members can subjectively affect the relationship, and therefore the achievement of objectives. It was found in the Chinese enterprises the lack of action plans focused on their organization, which limits the establishment of responsibilities and internal communication.

Regarding the use of strategic tools, the test results show that the companies that use more these instruments, have a higher degree of formality of planning, however, they use of tools in a limited way, either by ignorance or because managers are not convinced of the practical benefits of its use. It may also be indicative that the diversity of tools that can be used has not permeated in the business practice. Finally, there is evidence that the uses of tools of accounting and financial management influence the level of formality of the planning and performance of the company and are used in greater extent than strategic management tools, indicating an emphasis on the short term and the lack of a strategic vision.

Also, one of the overriding principles for the lack of competitiveness is that most organizations emerged in order to meet basic needs of the family and not with a view of development and competitiveness, therefore these businesses lack plans for growth in the medium and long term. Thus can confirm that you is not enough the daily administration for the strategic planning process, because do not allow them to have different courses of action which could define their strategies to cope with the competition they face day by day.

It is important that companies develop a more detailed internal and external analysis to establish a strategy to help them become more competitive in their environment. Because of cultural issues, they remain leaving the management of their organization to founders, who deserve respect and admiration because of their gender and age, ie the experience still imposed over strategic planning, this is the way they have carried out the administrative management labor.

\section{References}

[1] Ackoff, R. (1997). Planificación de la empresa del futuro. Limusa, México.

[2] Alcocer, A. (2009). Diccionario incompleto de la globalización. Taurus, México.

[3] Arellano, S. (2012). Mexicali, una ciudad con ascendencia china. El Universal. Sección Estados. http://www.eluniversal.com.mx/estados/85041.html

[4] Basco, J.T. (2006). La Investigación En La Empresa Familiar: Un Debate Sobre La Existencia De Un Campo Independiente. Investigaciones Europeas en Dirección y Economía de la Empresa, 12(1), 33-54.

[5] Casillas, J. y Acedo, F. (2007). "Evolution of Intellectual Structure of Family Business Literature: A Bibliometric Study of FRB” en family Business Review, vol 20, num 2, pp.141

[6] Cisneros, L.F. (2007). Seminario "Dirección de Empresas Familiares" en el V Congreso Internacional de Análisis Organizacional, Guanajuato, México.

[7] Chiavenato I., Sapiro, A. (2011). Planeación Estratégica. Fundamentos y aplicaciones. Brasil: McGrawHill. ISBN: 978970-10-6877-9

[8] Díaz, H. (2013). Las reglas de convivencia y su incidencia en la continuidad de las empresas familiares de Tehuacán. Global Conference on Business and Finance Proceedings. Volumen 8. Number 2.

[9] Dreux. I. \& B. Brown. 1999. Marketing private banking services to family businesses. Consultada en http://www.genuresources.com/Mark.priv.bank. Dreux_5.html.

[10] Gersick, K., J. Davis, M. Hampton \& I. Lansberg. 1997. Generation to generation: Life cycles of the family business. Boston, MA: Harvard Business School.

[11] Ghua, J., J. Chrisman \& P. Sharma. 1999. "Denning the family business by behavior". Entrepreneurship Theory and Practice, 23(4).

[12] Hernández R., Fernández, C. y Baptista, P. (2014) Metodología de la investigación. México: Mc Graw Hill.

[13] Hill, Ch. y Jones, G. (2009). Administración estratégica. México: Mc Graw Hill.

[14] INEGI (2010). Instituto Nacional de Estadística y Geografía. Consultado en http://www.inegi.org.mx/ 
[15] Kast F. y Rosenzweig J. (2004). Administración de las organizaciones. Un enfoque de sistemas y contingencias, Mc Graw Hill, México.

[16] Katz, M. 2005. "Planning for the Success of Your Family Business" Women in Business. Kansas City. Mayo. Tomo 57, $\mathrm{N}^{\mathrm{o}} 3$.

[17] Lansberg, I. S. 1988. "The succession conspiracy". Family Business Review, 1(2).

[18] Litz, R. 1995. "The family business: Towards definitional clarity". Family Business Review, 8(2)

[19] Longenecker, J. (2010) Administración de pequeñas empresas. México: Cengage Learning.

[20] Molina, V. (2006). Estrategias para el inicio y manejo exitoso de un changarro. México: ISEF.

[21] Lozano, O. Niebla, J., Cisneros, L. y De la Rosa, A. (2011). Metodología y estudio de la empresa Familiar. México: Grupo Editorial HESS, S.A. DE C.V. ISBN: 978-607-9011-09-3
[22] Poza E. (2005). Empresas familiares. México: Thomson

[23] Rodríguez, J. (2002), Administración de pequeñas y medianas empresas. México: Thomson.

[24] Rodríguez, J. (2005). Dirección moderna de las organizaciones, Thompson, México.

[25] Urzúa, (2012). Empresas Familiares: Lo primero es el negocio. KPMG México. Consultado en : http://www.conpapa.org.mx/files/congress/2012/conferences /empresas_familiares_primero_negocio.pdf

[26] Rodríguez, J (2006): Como aplicar la planeación estratégica a la pequeña y mediana empresa, Quinta Edición, International Thomson, México.

[27] Ward, J. L. 1987. Keeping the family business healthy. San Francisco, CA. Jossey Bass 